\title{
Salegentibacter holothuriorum sp. nov., isolated from the edible holothurian Apostichopus japonicus
}

\author{
Correspondence \\ Olga I. Nedashkovskaya \\ olganedashkovska@piboc.dvo.ru \\ or \\ olganedashkovska@yahoo.com
}

\author{
Olga I. Nedashkovskaya, ${ }^{1}$ Makoto Suzuki, ${ }^{2}$ Marc Vancanneyt, ${ }^{3}$ \\ Ilse Cleenwerck, ${ }^{3}$ Natalia V. Zhukova, ${ }^{4}$ Mikhail V. Vysotskii, ${ }^{4}$ \\ Valery V. Mikhailov ${ }^{1}$ and Jean Swings ${ }^{3}$ \\ ${ }^{1}$ Pacific Institute of Bioorganic Chemistry of the Far-Eastern Branch of the Russian Academy \\ of Sciences, Prospekt 100 Let Vladivostoku 159, 690022 Vladivostok, Russia \\ ${ }^{2}$ Tokyo Research Laboratories, Kyowa Hakko Kogyo Co. Ltd, 3-6-6 Asahi-machi, Machida-shi, \\ Tokyo 194-8533, Japan \\ ${ }^{3}$ BCCM/LMG Bacteria Collection, Laboratory of Microbiology, Ghent University, \\ Ledeganckstraat 35, B-9000 Ghent, Belgium
${ }^{4}$ Institute of Marine Biology of the Far-Eastern Branch of the Russian Academy of Sciences, Pal'chevskogo Street 17, 690032 Vladivostok, Russia

The genus Salegentibacter belongs to the family Flavobacteriaceae of the phylum Cytophaga-FlavobacteriumBacteroides. It was created by McCammon \& Bowman (2000) to accommodate moderately halophilic, yellowpigmented, non-gliding bacteria that were isolated from a hypersaline, meromictic lake in Antarctica. At present, this genus comprises a single species, Salegentibacter salegens, formerly Flavobacterium salegens (Dobson et al., 1993).

An unknown marine bacterium, strain KMM $3524^{\mathrm{T}}$, was isolated from the edible holothurian Apostichopus japonicus inhabiting the Sea of Japan. The $16 \mathrm{~S}$ rDNA sequence obtained in this study revealed that strain KMM $3524^{\mathrm{T}}$ belongs to the genus Salegentibacter. DNA-DNA hybridization, phenotypic and chemotaxonomic data indicated clearly that the holothurian isolate represents a novel species of the genus Salegentibacter, for which the name Salegentibacter holothuriorum sp. nov. is proposed.

Strain KMM $3524^{\mathrm{T}}$ was isolated aseptically from the

Published online ahead of print on 9 January 2004 as DOI 10.1099/ ijs.0.02987-0.

The GenBank/EMBL/DDBJ accession number for the $16 \mathrm{~S}$ rDNA sequence of Salegentibacter holothuriorum KMM $3524^{\top}$ is AB116148. holothurian A. japonicus, collected in Troitsa Bay, Gulf of Peter the Great, Sea of Japan (Pacific Ocean), from a depth of $8 \mathrm{~m}$ (salinity, $33 \%$; temperature, $12{ }^{\circ} \mathrm{C}$ ), in November 1997. For strain isolation, $0.1 \mathrm{ml}$ tissue homogenate was transferred onto plates that contained marine agar 2216 (Difco). After primary isolation and purification, strains were cultivated at $28{ }^{\circ} \mathrm{C}$ on the same medium and stored at $-80{ }^{\circ} \mathrm{C}$ in marine broth (Difco) supplemented with $20 \%$ (v/v) glycerol.

The 16S rRNA gene sequence of strain KMM $3524^{\mathrm{T}}$ was determined by PCR amplification and direct sequencing (Hiraishi, 1992). Conditions and reagents used for PCR amplification and sequencing of $16 \mathrm{~S}$ rDNA were as described previously (Suzuki et al., 2001). The sequence determined was aligned with an alignment based on the secondary-structure model that is maintained by the European small-subunit rRNA database (Van de Peer et al., 2000), by using the profile-alignment program of CLUSTAL W software (Thompson et al., 1994). Evolutionary distances were then computed with the DNADIST program in the PHYLIP package, version 3.572 (Felsenstein, 1995) with the two-parameter model (Kimura, 1980); a phylogenetic tree was constructed by using the neighbour-joining method (Saitou \& Nei, 1987). To evaluate phylogenetic 
trees, bootstrap analysis with 1000 sample replications was performed with the SEQBOOT and CONSENSE programs in the PHYLIP package, version 3.572.

Strain KMM $3524^{\mathrm{T}}$ showed highest $16 \mathrm{~S}$ rDNA sequence similarity to $S$. salegens DSM $5424^{\mathrm{T}}(98 \cdot 1 \%)$, indicating that strain KMM $3524^{\mathrm{T}}$ is a member of the family Flavobacteriaceae and belongs to the genus Salegentibacter (Fig. 1).

Gram-staining reaction, hydrolysis of elastin and Tweens 20,40 and 80 , nitrate reduction, production of hydrogen sulphide and indole, $\beta$-galactosidase, oxidase, catalase and alkaline phosphatase activities were tested according to the methods of Gerhardt et al. (1994). The medium of Hugh \& Leifson (1953), modified for marine bacteria (Lemos et al., 1985), was used to test for oxidative or fermentative utilization of glucose. Degradation of agar, starch, casein, gelatin, cellulose (filter paper and CM-cellulose), chitin, DNA, urea and alginic acids, flexirubin production, growth at different $\mathrm{pH}$ values, production of acid from carbohydrates and susceptibility to antibiotics were tested as described previously (Nedashkovskaya et al., 2003a). Growth at different temperatures and salinities was tested as described by Nedashkovskaya et al. (2003b). Carbonsource utilization was tested in a medium that contained $0 \cdot 2 \mathrm{~g} \mathrm{NaNO}_{3}, 0 \cdot 2 \mathrm{~g} \mathrm{NH}_{4} \mathrm{Cl}, 0 \cdot 05 \mathrm{~g}$ yeast extract (Difco) and $0.4 \%(\mathrm{w} / \mathrm{v})$ carbon source in $1000 \mathrm{ml}$ artificial sea water. Carbon sources tested were arabinose, glucose, lactose, mannose, sucrose, inositol, sorbitol, mannitol, fumarate, citrate and malonate. Spreading growth was observed by cultivation on medium that contained $\left(1^{-1}\right): 1 \mathrm{~g}$ Bacto peptone (Difco), $1 \mathrm{~g}$ yeast extract (Difco), $15 \mathrm{~g}$ agar and half-strength natural sea water under high-moisture conditions. Gliding motility was determined as described by Bowman (2000).
Physiological, morphological and biochemical characteristics of the strains studied are listed in the species description and in Table 1. Similarities in phenotypic characteristics support the inclusion of strain KMM $3524^{\mathrm{T}}$ in the genus Salegentibacter. However, strain KMM $3524^{\mathrm{T}}$ clearly differed from strains of $S$. salegens by its inability to grow in $12 \% \mathrm{NaCl}$ and to reduce nitrates to nitrites, its maximum growth temperature $\left(37^{\circ} \mathrm{C}\right)$, oxidation of lactose, fucose and $\mathrm{N}$-acetylglucosamine, utilization of sucrose and lactose and resistance to streptomycin (Table 1).

To detect whole-cell fatty acid profiles, the strain studied was grown at $28^{\circ} \mathrm{C}$ for $48 \mathrm{~h}$ on marine agar 2216 (Difco). Analysis of fatty acid methyl esters was performed by using GLC [30 m $\times 0.25 \mathrm{~mm}$ Supelcowax 10 column (Supelco), $\left.205^{\circ} \mathrm{C}\right]$ as described by Svetashev et al. (1995). Predominant cellular fatty acids were branched-chain saturated and unsaturated and straight-chain saturated and unsaturated, namely i15:0 (26.3\%), i15:1 (18.2\%), 15:0 (9.6\%), $16: 1 \omega 7(10 \cdot 4 \%)$, i17: $1(8 \cdot 0 \%)$ and i15:0 $2-\mathrm{OH}(7 \cdot 9 \%)$ and corresponded with the fatty acid composition of S. salegens DSM $5424^{\mathrm{T}}$, determined under the same conditions (data not shown). Lipids were extracted according to the method of Bligh \& Dyer (1959), as modified by Svetashev \& Vaskovsky (1972) and Vaskovsky et al. (1975). The main polar lipid was phosphatidylethanolamine. Isoprenoid quinones were extracted and analysed by the method of Nakagawa \& Yamasato (1993). The major lipoquinone was MK-6, a feature that is characteristic of the Flavobacteriaceae.

For determination of DNA G + C content and DNA-DNA binding values, DNA was prepared from cells that had been cultivated on marine agar (Difco) for $24-48 \mathrm{~h}$ at $25^{\circ} \mathrm{C}$, according to the DNA extraction protocol of Pitcher et al.

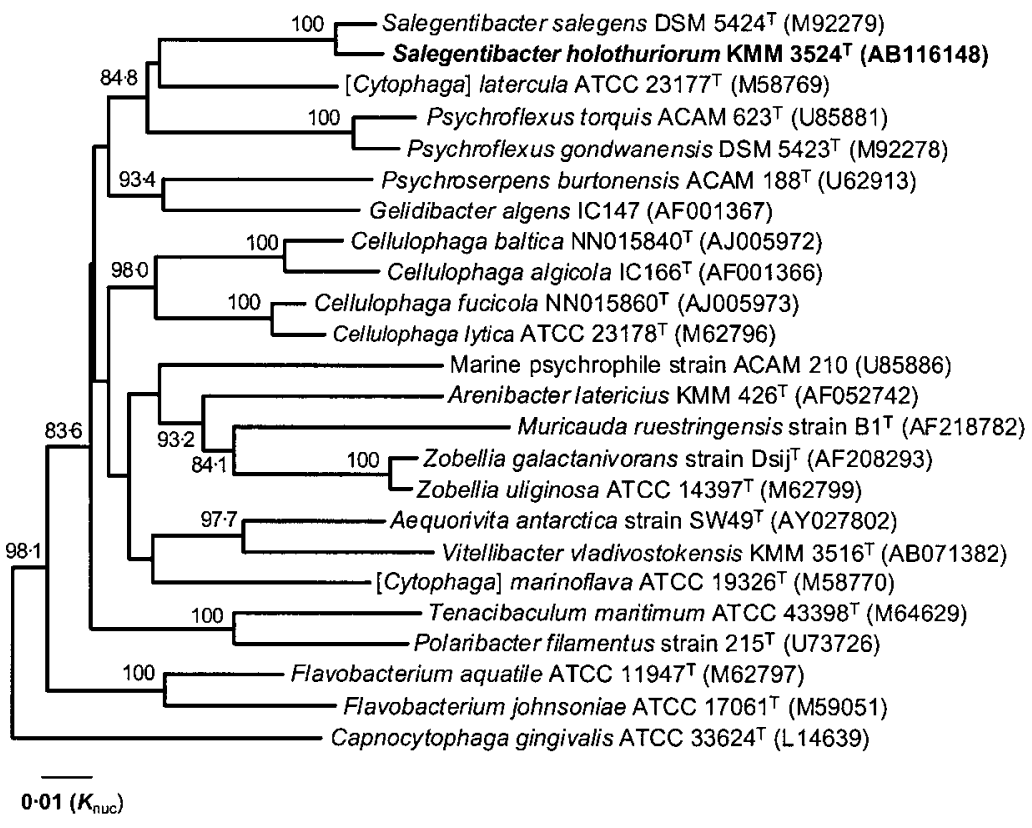

Fig. 1. Phylogenetic relationships between strain KMM $3524^{\top}$ and marine species of the family Flavobacteriaceae on the basis of $16 \mathrm{~S}$ rDNA sequence comparison. The phylogenetic tree was generated by the neighbourjoining method (Saitou \& Nei, 1987). The 16S rDNA sequence of Capnocytophaga gingivalis (GenBank accession no. L14639) was used as the outgroup. The number shown next to each node indicates the percentage bootstrap value of 1000 replicates (only values of $70 \%$ or more are shown). Bar, genetic distance of $0.01\left(K_{\text {nuc }}\right)$. 
Table 1. Phenotypic characteristics of members of the genus Salegentibacter

Strains: 1, S. holothuriorum KMM $3524^{\mathrm{T}} ; 2$, S. salegens DSM $5424^{\mathrm{T}}$. Both strains gave positive results in tests for the following characteristics: respiratory metabolism; oxidase, catalase, $\beta$ galactosidase and alkaline phosphatase activities; hydrolysis of Tweens 20, 40 and 80, gelatin, elastin, starch, alginic acids and DNA; requirement for $\mathrm{NaCl}$ for growth; growth at $34^{\circ} \mathrm{C}$ and in $8 \% \mathrm{NaCl}$; acid formation from galactose, glucose and maltose; utilization of glucose and mannose; $\mathrm{H}_{2} \mathrm{~S}$ production; susceptibility to ampicillin, benzylpenicillin, carbenicillin, lincomycin, oleandomycin and tetracycline; resistance to gentamicin, kanamycin, neomycin and polymyxin B. Strains KMM $3524^{\mathrm{T}}$ and DSM $5424^{\mathrm{T}}$ both gave negative results results in tests for the following characteristics: motility by gliding; hydrolysis of agar, casein, cellulose (CM-cellulose and filter paper), urea and chitin; acid production from arabinose, cellobiose, melibiose, rhamnose, sucrose, sorbose, xylose, succinate, citrate, glycerol, adonitol, dulcitol, sorbitol, inositol and mannitol; utilization of arabinose, inositol, mannitol, sorbitol, malonate and citrate; indole and acetoin (VogesProskauer reaction) production.

\begin{tabular}{|lcc|}
\hline Characteristic & $\mathbf{1}$ & $\mathbf{2}$ \\
\hline Nitrate reduction & - & + \\
Growth at/in: & & \\
$\quad 37^{\circ} \mathrm{C}$ & + & - \\
$12 \% \mathrm{NaCl}$ & - & + \\
Acid from: & & - \\
$\quad$ Lactose & + & - \\
Fucose & + & - \\
$\quad N$-Acetylglucosamine & + & + \\
Utilization of: & & - \\
$\quad$ Sucrose & - & + \\
$\quad$ Lactose & + & $36 \cdot 7$ \\
Susceptibility to streptomycin & - & \\
DNA G $+C$ content (mol\%) & $36 \cdot 8$ & \\
\end{tabular}

(1989) as modified by Leisner et al. (2002). The G+C content was determined [by using the HPLC method of Mesbah et al. (1989)] to be $36 \cdot 8 \mathrm{~mol} \%$, a value that is analogous to that described for $S$. salegens. DNA-DNA hybridizations were performed by using the microplate method and fluorescence measurements for calculation of binding values, as described by Ezaki et al. (1989). Hybridizations between strains KMM $3524^{\mathrm{T}}$ and S. salegens DSM $5424^{\mathrm{T}}$ were performed at $35^{\circ} \mathrm{C}$ in a hybridization mixture ( $2 \times$ SSC, $5 \times$ Denhardt's solution, $2.5 \%$ dextran sulphate, $50 \%$ formamide, $100 \mu \mathrm{g}$ denaturated salmon sperm DNA $\mathrm{ml}^{-1}, 1250 \mathrm{ng}$ biotinylated probe DNA ml${ }^{-1}$ ) and yielded a relatedness value of $38 \%$.

We can conclude that the genomic data, supported by phenotypic findings and chemotaxonomic characteristics, clearly classify strain KMM $3524^{\mathrm{T}}$ in the genus Salegentibacter as the type strain of a novel species, for which we propose the name Salegentibacter holothuriorum sp. nov.

\section{Description of Salegentibacter holothuriorum sp. nov.}

Salegentibacter holothuriorum (ho.lo.thu.ri.o'rum. N.L. gen. pl. n. holothuriorum of holothurians, sea cucumbers; bacterium isolated from holothurians).

Cells are Gram-negative, strictly aerobic, chemo-organotrophic, non-motile, asporogenic rods, $0 \cdot 5-0 \cdot 7 \mu \mathrm{m}$ wide and $2 \cdot 7-5 \cdot 3 \mu \mathrm{m}$ long. Oxidase-, catalase-, $\beta$-galactosidaseand alkaline phosphatase-positive. Colonies are circular, convex, shiny with entire edges and $1-3 \mathrm{~mm}$ in diameter on marine agar 2216. Yellow, non-diffusible pigments are produced. No growth is observed without $\mathrm{Na}^{+}$. Growth occurs in $1-8 \% \mathrm{NaCl}$. Flexirubin pigments are absent. Growth is detected at 4 and $37^{\circ} \mathrm{C}$. Gelatin, starch, alginic acids, DNA and Tweens 20, 40 and 80 are hydrolysed, but agar, casein, cellulose (CM-cellulose and filter paper), chitin and urea are not. Acid is formed from galactose, glucose, lactose, maltose, fucose and $\mathrm{N}$-acetylglucosamine, but not from arabinose, cellobiose, melibiose, raffinose, rhamnose, sorbose, sucrose, xylose, adonitol, dulcitol, glycerol, inositol, sorbitol or mannitol. Utilizes glucose, lactose and mannose, but not arabinose, sucrose, inositol, sorbitol, mannitol, citrate or malonate. $\mathrm{H}_{2} \mathrm{~S}$ is produced. Nitrate is not reduced. No indole or acetoin (VogesProskauer reaction) is produced. Susceptible to ampicillin, benzylpenicillin, carbenicillin, oleandomycin, lincomycin and tetracycline. Resistant to kanamycin, neomycin, streptomycin, gentamicin and polymyxin B. Predominant

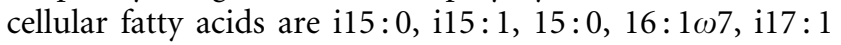
and i15:0 2-OH. Major isoprenoid quinone is MK-6. Main polar lipid is phosphatidylethanolamine. DNA G +C content is $36 \cdot 8 \mathrm{~mol} \%$.

The type strain is $\mathrm{KMM} 3524^{\mathrm{T}}\left(=\mathrm{NBRC} 100249^{\mathrm{T}}=\right.$ LMG $21968^{\mathrm{T}}$ ). Isolated from the holothurian Apostichopus japonicus living in the Sea of Japan.

\section{Acknowledgements}

We are grateful to Dr J. Euzéby for his help with nomenclature. This research was supported by grants from the Ministry for Industry, Science and Technologies of the Russian Federation (2-2.16), the Russian Foundation for Basic Research (02-04-49517) and Presidium and FEB RAS 'Molecular and Cell Biology'. We thank C. Snauwaert for excellent technical assistance.

\section{References}

Bligh, E. G. \& Dyer, W. J. (1959). A rapid method of total lipid extraction and purification. Can J Med Sci 37, 911-917.

Bowman, J. P. (2000). Description of Cellulophaga algicola sp. nov., isolated from the surfaces of Antarctic algae, and reclassification of Cytophaga uliginosa (ZoBell and Upham 1944) Reichenbach 1989 as Cellulophaga uliginosa comb. nov. Int J Syst Evol Microbiol 50, 1861-1868.

Dobson, S. J., Colwell, R. R., McMeekin, T. A. \& Franzmann, P. D. (1993). Direct sequencing of the polymerase chain reactionamplified 16S rRNA gene of Flavobacterium gondwanense sp. nov. 
and Flavobacterium salegens sp. nov., two new species from a hypersaline Antarctic lake. Int J Syst Bacteriol 43, 77-83.

Ezaki, T., Hashimoto, Y. \& Yabuuchi, E. (1989). Fluorometric deoxyribonucleic acid-deoxyribonucleic acid hybridization in microdilution wells as an alternative to membrane filter hybridization in which radioisotopes are used to determine genetic relatedness among bacterial strains. Int J Syst Bacteriol 39, 224-229.

Felsenstein, F. (1995). PHYLIP (Phylogeny Inference Package) version 3.57c. Seattle: University of Washington.

Gerhardt, P., Murray, R. G. E., Wood, W. A. \& Krieg, N. R. (editors) (1994). Methods for General and Molecular Bacteriology. Washington, DC: American Society for Microbiology.

Hiraishi, A. (1992). Direct automated sequencing of $16 \mathrm{~S}$ rDNA amplified by polymerase chain reaction from bacterial cultures without DNA purification. Lett Appl Microbiol 15, 210-213.

Hugh, R. \& Leifson, E. (1953). The taxonomic significance of fermentative versus oxidative metabolism of carbohydrates by various gram-negative bacteria. J Bacteriol 66, 24-26.

Kimura, M. (1980). A simple method for estimating evolutionary rates of base substitutions through comparative studies of nucleotide sequences. J Mol Evol 16, 111-120.

Leisner, J. J., Vancanneyt, M., Lefebvre, K., Vandemeulebroecke, K., Hoste, B., Euras Vilalta, N., Rusul, G. \& Swings, J. (2002). Lactobacillus durianis sp. nov., isolated from an acid-fermented condiment (tempoyak) in Malaysia. Int J Syst Evol Microbiol 52, 927-931.

Lemos, M. L., Toranzo, A. E. \& Barja, J. L. (1985). Modified medium for the oxidation-fermentation test in the identification of marine bacteria. Appl Environ Microbiol 49, 1541-1543.

McCammon, S. A. \& Bowman, J. P. (2000). Taxonomy of Antarctic Flavobacterium species: description of Flavobacterium gillisiae sp. nov., Flavobacterium tegetincola sp. nov. and Flavobacterium xanthum sp. nov., nom. rev. and reclassification of [Flavobacterium] salegens as Salegentibacter salegens gen. nov., comb. nov. Int J Syst Evol Microbiol 50, 1055-1063.

Mesbah, M., Premachandran, U. \& Whitman, W. B. (1989). Precise measurement of the $\mathrm{G}+\mathrm{C}$ content of deoxyribonucleic acid by high-performance liquid chromatography. Int J Syst Bacteriol 39, 159-167.
Nakagawa, Y. \& Yamasato, K. (1993). Phylogenetic diversity of the genus Cytophaga revealed by $16 \mathrm{~S}$ rRNA sequencing and menaquinone analysis. J Gen Microbiol 139, 1155-1161.

Nedashkovskaya, O. I., Suzuki, M., Vysotskii, M. V. \& Mikhailov, V. V. (2003a). Reichenbachia agariperforans gen. nov., sp. nov., a novel marine bacterium in the phylum Cytophaga-FlavobacteriumBacteroides. Int J Syst Evol Microbiol 53, 81-85.

Nedashkovskaya, O. I., Kim, S. B., Han, S. K. \& 7 other authors (2003b). Mesonia algae gen. nov., sp. nov., a novel marine bacterium of the family Flavobacteriaceae isolated from the green alga Acrosiphonia sonderi (Kütz) Kornm. Int J Syst Evol Microbiol 53, 1967-1971.

Pitcher, D. G., Saunders, N. A. \& Owen, R. J. (1989). Rapid extraction of bacterial genomic DNA with guanidium thiocyanate. Lett Appl Microbiol 8, 151-156.

Saitou, N. \& Nei, M. (1987). The neighbor-joining method: a new method for reconstructing phylogenetic trees. Mol Biol Evol 4, 406-425.

Suzuki, M., Nakagawa, Y., Harayama, S. \& Yamamoto, S. (2001). Phylogenetic analysis and taxonomic study of marine Cytophaga-like bacteria: proposal for Tenacibaculum gen. nov. with Tenacibaculum maritimum comb. nov. and Tenacibaculum ovolyticum comb. nov., and description of Tenacibaculum mesophilum sp. nov. and Tenacibaculum amylolyticum sp. nov. Int J Syst Evol Microbiol 51, 1639-1652.

Svetashev, V. I. \& Vaskovsky, V. E. (1972). A simplified technique for thin-layer microchromatography of lipids. J Chromatogr 67, 376-378.

Svetashev, V. I., Vysotskii, M. V., Ivanova, E. P. \& Mikhailov, V. V. (1995). Cellular fatty acid of Alteromonas species. Syst Appl Microbiol 18, 37-43.

Thompson, J. D., Higgins, D. G. \& Gibson, T. J. (1994). CLUSTAL W: improving the sensitivity of progressive multiple sequence alignment through sequence weighting, position-specific gap penalties and weight matrix choice. Nucleic Acids Res 22, 4673-4680.

Van de Peer, Y., De Rijk, P., Wuyts, J., Winkelmans, T. \& De Wachter, R. (2000). The European small subunit ribosomal RNA database. Nucleic Acids Res 28, 175-176.

Vaskovsky, V. E., Kostetsky, E. Y. \& Vasendin, I. M. (1975). A universal reagent for phospholipid analysis. J Chromatogr 114, 129-141. 